\title{
Accountability Guidance and Counseling Program in the City of Banjarmasin Vocational School
}

\author{
Muhammad Yuliansyah ${ }^{1 *}$, I Nyoman Sujana Degeng ${ }^{2}$, Bambang Budi \\ Wiyono $^{3}$, Achmad Supriyanto ${ }^{4}$ Jarkawi $^{5}$, Murdiansyah Herman ${ }^{6}$ \\ 1,5,6 Universitas Islam Kalimantan Mubammad Arsyad Al Banjari \\ 2,3,4 Universitas Negeri Malang
}

Corresponding Author: ${ }^{1^{*}}$ m.yuliansyaby@yahoo.com

\begin{abstract}
The existence of guidance and counseling is a basic need that must be prioritized in the life of the community Guidance and Counseling Services that are good and Article History: right, effective and efficient in developing guidance and counseling missions so that community recognition and trust will increase. Accountability is carried out periodically and in accordance with the provisions with effective documentation through measurement of results from professional activities. Accountability refers to

Revised: accountability for the success or failure of achieving the results of an organization's program. The guidance and counseling profession as professional counselors masters Accepted: and realizes their professional practice, the accountability of guidance and counseling must be carried out as an embodiment of the obligation to account for the success or failure of implementing the guidance and counseling program mission in achieving thestatedgoals and objectives.
\end{abstract}

Keywords: Accountability; Guidance and Counseling; Programs.

Journal Homepage http://ijssr.net/index.php/ijssr

This is an Open Access article under the CC BY SA license https://creativecommons.org/licenses/by-sa/4.0/

Published by Indonesian Academy of Social and Religious Research 


\section{Introduction}

Schools are formal institutions that are specifically formed to provide education for community members. The direction of the formation of this institution is to provide ease of achieving optimal development of students. To achieve optimal self-development, in the school institution is realized by the existence of the field of educational services, one of which is the guidance and counseling services in schools. Guidance and counseling is an integral part of education which has strategic functions and roles.

Counseling guidance services make students able to know themselves, their environment, and able to plan for their future. This is reinforced by the explanation from that the general purpose of guidance and counseling is to help individuals develop optimally in accordance with the stages of development and competencies owned by individuals (such as basic competencies and talents), various backgrounds that exist (such as family background, education, socioeconomic status), and in accordance with the positive demands of their environment. ${ }^{1}$ Counseling guidance services are determined by the cooperation of all school personnel, but the hard work and seriousness of the counselors in carrying out the task, is the main key to the success of the service, which ultimately, can contribute to the realization of quality human resources. Guidance and Counseling in Indonesia is a problem, so the problem must be addressed so that in the future it can develop better and with dignity. ${ }^{2}$

The problems faced start from the lack of budget for education in BK activities in schools, the minimum skill of BK personnel in school settings in planning the BK program. All of this is a matter of educational problems in Guidance and Koseling where the spearhead is for students to live meaningfully so that in line with education is "to humanize human beings by increasing all competencies that exist in themselves, such as intellectual, emotional and spiritual competence. ${ }^{3}$

Accountability of guidance and counseling programs is very important to be a concern for teachers of guidance and counseling. ${ }^{4}$ Because before carrying out various counseling activities, the guidance and counseling teacher must

1 R L Gibson and M H Mitchell, "Bimbingan Dan Konseling. Yogyakarta: Pustaka Pelajar. Diterjemahkan Dari; Introduction to Counseling and Guidance” (First publisher, 2008).

2 Gibson and Mitchell.

3 Lisnawati Soapatty, "Pengaruh Sistem Sekolah Sehari Penuh (Full Day School) Terhadap Prestasi Akademik Siswa Smp Jati Agung Sidoarjo," E-Journal UNESA 2, no. 2 (2014): 719-33.

4 Phyllis Niles, "Meeting the Needs of the 21st Century Student," Community E Junior College Libraries 17, no. 2 (2011): 47-51. 
understand the performance and the things to be accounted for, in accordance with the standards of the guidance and counseling program, thus the existence of guidance and counseling has the trust of the wider community (stakeholder). ${ }^{5}$ Guidance and counseling teachers or counselors really need to arrange a program that suits the needs of students or the community. The existence of a systematic program, requires certain conditions to be accounted for, while the conditions for being accountable require standards as a measure of success or achievement achieved by the supervising teacher. ${ }^{6}$

The implementation of guidance and counseling services that is good and right, effective and efficient and productive in developing agreed guidance and counseling missions is essential, so that community recognition and trust will increase. If the accountability or accountability of guidance and counseling is done periodically and in accordance with the provisions or rules that apply and adhere to the principle, of course the existence of guidance and counseling is a basic need that must be prioritized in people's lives. ${ }^{7}$

\section{Methods}

This study used a qualitative approach. According to Moeloeng, a qualitative approach is a form of research work flow with inductive, holistic and process oriented.

This study was a case study with multisite design. A case study, according to Yin, is a type of empirical research that investigates phenomena in real life and utilizes multiple sources as evidence. ${ }^{8}$ Meanwhile, according to Bogdan and Biklen, multi-site design is a form of qualitative research design to develop selected theories from several similar backgrounds. ${ }^{9}$

This research was conducted at Vocational School at Banjarmasin City, which had the same character such as level equality, urban location conditions and

5 John J Schmidt, Counseling in Schools: Essential Services and Comprehensive Programs (Allyn \& Bacon, 2003).

6 Dilani M Perera-Diltz and Kimberly L Mason, "An Exploration of Accountability Practices of School Counselors: A National Study," Journal of Professional Counseling: Practice, Theory E Research 38, no. 1 (2010): 52-70.

7 Carey Dimmitt, "Why Evaluation Matters: Determining Effective School Counseling Practices," Professional School Counseling 12, no. 6 (2009): 2156759X0901200605.

8 Matthew B Miles, A Michael Huberman, and Johnny Saldaña, Qualitative Data Analysis: A Methods Sourcebook (Sage publications, 2018).

9 Robert Bogdan and Sari Knopp Biklen, Qualitative Research for Education (Allyn \& Bacon Boston, MA, 1997). 
school status are the same as state schools. For data collection using observation, interviews and documentation. After the data is collected, the data validity will be carried out using credibility, transferbility, dependability and confirmation, which will then be analyzed using the Miles and Hubberman model analysis a way that is done by working with data, organizing data, sorting data, synthesizing data, searching and finding patterns. ${ }^{10}$

\section{Result and Discussion}

A. Accountability

Literally the concept of accountability comes from two words namely "account" (accounts, reports or notes) and "abilities" (abilities). Accountability can be interpreted as the ability to show reports or records that can be accounted. ${ }^{11}$ Accountability comes from the English language "Accountability" means the condition to be accounted for. Accountability is also called performance then defines "accountability as the responsibility for something to someone with consequences that can be predicted for the desired performance and can be understood from what is accountable". ${ }^{12}$ Stated that accountability is aimed at finding answers to questions relating to stewardship, namely what, why, who, where, which, and how an accountability must be carried out. Meanwhile said that accountability is an evolution of the activities carried out by an officer who is in the path of his authority and Everyone must really realize that every action will not only affect themselves. However, he must realize that his actions will also have a significant impact on others. ${ }^{13}$

Accountability is intended as documenting effectiveness through measuring the results of professional activities, generally including several activities, namely: (1) identification of needs; (2) formulating objectives based on needs; (3) implementing programs to meet needs; (d) measuring program results; (e) use measurement results to modify and improve the program and; (f) communicating

10 Miles, Huberman, and Saldaña, Qualitative Data Analysis: A Methods Sourcebook.

11 Edi Suharto, "Menengok Kriteria Kemiskinan Di Indonesia: Menimbang Indikator Kemiskinan Berbasis Hak," Jurnal Analisis Sosial, 2009, 31-39.

12 James Baisie Ghartey, Crisis Accountability and Development in the Third World: The Case of Africa (Gower Publishing Company, 1987).

13 L-V CARINO, "Administrative Accountability: A Review of the Evolution, Meaning and Operationalization of a Key Concept in Public Administration," Philippine Journal of Public Administration Manila 27, no. 2 (1983): 118-48. 
results to parents or guardians, principals, teachers, school committees and colleagues. ${ }^{14}$

The basic concept of accountability is based on the classification of managerial responsibility at each level in an organization, which aims to carry out activities in each section, Each unit in an organization, even though the small ones are responsible for every activity carried out on their part. They have a specific task load and need to be held accountable to the assignor of that activity.

Accountability is not the same as responsibility. more accountability refers to the accountability of success or failure of achieving organizational results. If related to the guidance and counseling profession as professional counselors, the educator who masters and realizes his professional practice, the guidance and counseling accountability must be carried out as an embodiment of the responsibility to account for the success or failure of the implementation of the guidance and counseling mission in achieving the goals and objectives that have been achieved. set. Guidance and counseling accountability must be conveyed before the assignor / mandate about the success or failure of the implementation of the program, management and administration within a certain period of time

\section{B. The Use of Accountability in the Guidance and Counseling Program}

Accountability is very important to do to see the extent to which the program that we are running is in accordance with the stated goals, while the benefits are:

1. How after the BK program was made to students, parents, majors, and school climate.

2. How far the clients have succeeded in achieving the program objectives.

3. What things have not been achieved in the program.

4. Detect effective components in the program.

5. Eliminating or increasing components of programs that are less effective.

6. Filtering the implementation of the BK program process and its implementation.

7. Identifying various unintended consequences arising from the program

8. Serve the needs of staff and workload adjustments

9. Provide additional resources needed for the program to be achieved

14 Stephen Isaac and William Burton Michael, "Handbook in Research and Evaluation: For Education and the Behavioral Sciences," 1981. 
C. Forms of Guidance and Counseling Accountability

1. Program accountability.

Program accountability refers to the responsibility regarding the results of the BK activities that have been carried out. This will be closely related to the program plans prepared previously and will also display process accountability related to the process of implementing activities.

2. Management accountability.

Management accountability focuses on efficiency and effectiveness in the use of funds, facilities, human resources and other resources. This accountability shows the manager's role, not only in implementing existing regulations, but also in implementing an ongoing process, so that it is possible to provide the best service. This management accountability can be divided into financial, facility, administration, and human resources accountability

\section{Guidance and Counseling Criteria}

Criteria are the measurements on which something is based identified seven criteria that must be met if the accountability system is to achieve the desired results. ${ }^{15}$ These are as follows:

1. In order to be able to formulate what is the responsibility of the counselor, and the general purpose of counseling must of course be agreed by all interested parties.

2. What the counselor does and accomplishes must be stated in the formulation of changes in important client behavior that can be observed.

3. Activities conducted by the counselor are stated at least as costs not as work and achievements.

4. Accountability systems must be built with the aim of advancing professional effectiveness and to making improvements by themselves, not to show mistakes or punish poor performance.

5. In order for reports to be properly reported, reports of unknown failures and successes should not be prohibited.

15 Gibson and Mitchell, "Bimbingan Dan Konseling. Yogyakarta: Pustaka Pelajar. Diterjemahkan Dari; Introduction to Counseling and Guidance." 
6. All users of the accountability system must be included (represented) in designing the system.

7. The accountability system itself must be assessed and can be changed

\section{Discussion}

A. Supporting and inhibiting factors.

1. Supporting Factors.

Exemplary leadership. The program to be implemented should be properly carried out and through to completion. So that it can be clearly determined what are the objectives to be achieved and what are the performance indicators: ${ }^{16}$

a. Create good coordination between and between related units.

b. Define clear work standards.

c. Communicate to all parties the purpose and meaning of accountability.

2. Inhibiting factors.

Failure to implement accountability is largely determined by:

a. Low awareness about accountability.

b. Lack of willingness to implement accountability.

c. Decrease in normal values.

d. Cultural factors.

e. The low quality of officers / officials.

f. Environmental crisis.

g. Legal weaknesses regarding accountability.

h. Outdated technology. Low standard of living

B. Implications of Accountability and supervision of the Guidance and Counseling program

Implementing good accountability and supervision will have positive implications regarding the counselor (as the person who provides the service) and the institution (where the counselor works). This is reflected in the healthier and competitive management of the organization and management.

16 Robert D Myrick, "Accountability: Counselors Count," Professional School Counseling 6, no. 3 (2003): 174-79. 
Accountability is an activity that is written and carried out periodically that will lead to quality and ongoing Guidance and counseling activities as stated by [18] that the accountability or accountability of the implementation of the guidance and counseling program is carried out in accordance with the procedures and regulations so that guidance and counseling become needed in school life.

Accountability is an accountability teacher guidance and counseling that must be done as a material to report to stakeholders in their performance. ${ }^{17}$ As stated by in the Acontability Guidance and Counseling seminar at Uniska Muhammad Arsyad Al Banjari Banjarmasin stated that the accountability of guidance and counseli ${ }^{18}$ ng teachers is an accountability and or reporting of activities to stakeholders with recorded performance both successes and failures by professionals as a form of authority.

Accountability means that school counselors can account for the work documents they do for partners in the education process - students, parents and caregivers, colleagues at school, and colleagues in the community. An accountability system will allow the counselor to ${ }^{19}$ :

1. Get feedback about their work.

2. Counseling methods can be chosen based on the success that has been demonstrated.

3. Identifying counselees who so far have not met their needs.

4. Designing a short method for routine operational activities.

5. Exchange opinions with staff to improve the achievement of objectives and find solutions to problems that develop.

\section{Implementation Of BK Programs In Indonesia}

Before we discuss further about the implementation of the above description with the situation and conditions in Indonesia, then as a start, we will discuss a little about the evolution of the BK program in Indonesia. If we see how long the development of the BK accountability process in western countries, then what about in Indonesia?

17 Aris Setia Noor and Riadhul Muttaqin, "Akuntabilitas Sistem Informasi Manajemen Kearsipan Dan E-Dokumen," JPM (Jurnal Pemberdayaan Masyarakat) 3, no. 2 (2018): 264-71.

18 H Jarkawi et al., "MANAJEMEN STRATEGI MUTU LAYANAN BIMBINGAN DAN KONSELING BERORENTASI PUBLIC TRUST PADA SMKN DI BANJARMASIN,” n.d.

19 Gibson and Mitchell, "Bimbingan Dan Konseling. Yogyakarta: Pustaka Pelajar. Diterjemahkan Dari; Introduction to Counseling and Guidance." 
In Indonesia BK was introduced in schools around 1962 after officials of the Ministry of Education and Culture $(\mathrm{P} \& \mathrm{~K})$ instructed the formation of guidance and counseling services in secondary schools upon the return of a number of officials from the ministry of $\mathrm{P} \& \mathrm{~K}$ to conduct a review in the US. At that time the determination of the counselor assignment criteria (BP / BK / GC teacher) was unclear and very wide, ranging from roles such as "school police" to conversion of test results for all students in a school to a standard score. It was only in 1975 that BK services were included in the curriculum (known as the 1975 Curriculum). In the curriculum, BK service is one of the services in the school system, starting from elementary to high school level. In 1976 the provision of BK services was also included in the schooling system for SMK levels, but over time the BK service in SMKs was not followed up by SMK heads. In addition, the implementation of counseling at the elementary school level also did not go as expected, because there were no counselors appointed at the elementary school except perhaps at certain private schools. Although the law does not provide clear space for BK services, but because of the strong desire to strengthen this profession, the Indonesian Guidance Officers Association (IPBI) was established. This IPBI is a place for the counselor / guidance profession to work in the field.

In 1994 with the introduction of the 1994 curriculum, there was room for BK expert services in the school system in Indonesia because one of the provisions requires that each school provide 1 counselor for every 150 students (new BK activities are realized at the secondary education level). With this provision, the need for counselors in schools is increasing. Even so in the field, S1 BK graduates are still very minimal, especially added by the Directorate General of Higher Education policy to reduce the number of BK BK S1 in the entire country. The impact is that schools transfer the assignments of teachers who can be released (dispensable) to carry out the task of carrying out BK services after being trained through the Crash Program and the graduates are called Tutor Teachers.

In 2003 Law No. 20 of 2003 concerning the National Education System was enacted which stated that there was a counselor position in Article 1 paragraph (6). But in the next article there was no continuation regarding the counselor's position. This makes a lot of misinterpretations, especially about the duties and roles of counselors in school. The Act states that the counselor is an educator, because there is no further explanation then it is interpreted in general as the duties of the counselor as well as the teacher's task. Up to Law number 14 of 
2005 concerning Teachers and Lecturers also have not been found about the context of the task and expectations of counselor performance. Only in 2007 the Indonesian Guidance and Counseling Association (ABKIN d / h IPBI) compiled basic references for the provision of $\mathrm{BK}$ services, especially for formal education channels. With this reference BK service activities in Indonesia began to be reorganized in its operation according to the guidelines listed on the reference. In addition, the Ministry of National Education number 27 of 2008 concerning Academic Qualification Standards and Counselor Competencies also appeared. Thus legally the position of counselor as a profession can be at stake and can be held accountable, especially in the implementation of formal education.

From a brief description of the development of BK in Indonesia, a conclusion can be drawn that historically BK services in Indonesia have also gone a long way in affirming their existence as one of the professional services in the community. In addition, what needs to be observed is that the ups and downs of BK service provision in Indonesia give an indication that the issue of accountability still needs to be worked on seriously so that the service can appear truly professionally.

Accountability services are manifested in the clarity of the program, the process of implementation, and the results achieved as well as information that can explain what and why a process or outcome occurs or does not occur. There is a very important thing in accountability, namely information related to factors that influence the success and / or failure of students in achieving competence.

As a manifestation of the BK service accountability, especially in the formal education pathway, it is necessary to have a clear BK program and be based on the needs of its users (especially students) and also refer to the BK service evaluation results that have been held. It also means that the counselor needs to master and have the ability to collect data (and at the same time pay attention to up-to-date data) because of the data used as a basis for holding BK. Another thing about applying accountability is the operationalization (process) of the implementation of the program that has been made and what results have been achieved. From the results achieved it needs to be evaluated to find out whether or not a program is effective.

As has been done in western countries, evaluation as one of the basic development of a program. For the realization of a quality and effective and accountable program, the results that have been achieved in a program need to be informed. Besides that, it is very important as supporting material for a program, 
so a research is conducted so that the impact and effectiveness can be known. As an accountable profession, counselors at schools conduct research on the BK services they have conducted while reporting and documenting the results of their research. Reporting or instead of the word "inform" has a great value and effect on the existence of a BK program in schools. This can provide evidence that there are benefits that can be taken from a program that is carried out. In addition, it is also used as a comparison between one program to another. Thus, both personnel at school, parents and the community know and assess the impact of a program, especially for the development of students.

\section{Conclussion}

Accountability as documentation of effectiveness through measuring the results of professional activities, therefore accountability activities for the implementation of Guidance and Counseling activities are needed because through this activity can be reviewed programs that have been prepared can be implemented or not implemented, and can also be seen inhibiting factors and factors - supporting factors that can be evaluated for the following year's activities

\section{Reference}

Bogdan, Robert, and Sari Knopp Biklen. Qualitative Research for Education. Allyn \& Bacon Boston, MA, 1997.

CARINO, L-V. "Administrative Accountability: A Review of the Evolution, Meaning and Operationalization of a Key Concept in Public Administration." Philippine Journal of Public Administration Manila 27, no. 2 (1983): 118-48.

Dimmitt, Carey. "Why Evaluation Matters: Determining Effective School Counseling Practices." Professional School Counseling 12, no. 6 (2009): 2156759X0901200605.

Ghartey, James Baisie. Crisis Accountability and Development in the Third World: The Case of Africa. Gower Publishing Company, 1987.

Gibson, R L, and M H Mitchell. "Bimbingan Dan Konseling. Yogyakarta: Pustaka Pelajar. Diterjemahkan Dari; Introduction to Counseling and Guidance." First publisher, 2008.

Isaac, Stephen, and William Burton Michael. "Handbook in Research and Evaluation: For Education and the Behavioral Sciences," 1981. 
Jarkawi, H, Jarkawi MM Pd, Muhammad Eka Prasetia, Eka M Pd, and M M Mahfuz. "MANAJEMEN STRATEGI MUTU LAYANAN BIMBINGAN DAN KONSELING BERORENTASI PUBLIC TRUST PADA SMKN DI BANJARMASIN," n.d.

Miles, Matthew B, A Michael Huberman, and Johnny Saldaña. Qualitative Data Analysis: A Methods Sourcebook. Sage publications, 2018.

Myrick, Robert D. "Accountability: Counselors Count." Professional School Counseling 6, no. 3 (2003): 174-79.

Niles, Phyllis. "Meeting the Needs of the 21st Century Student." Community \& Junior College Libraries 17, no. 2 (2011): 47-51.

Noor, Aris Setia, and Riadhul Muttaqin. "Akuntabilitas Sistem Informasi Manajemen Kearsipan Dan E-Dokumen.” JPM (Jurnal Pemberdayaan Masyarakat) 3, no. 2 (2018): 264-71.

Perera-Diltz,Dilani M, and Kimberly L Mason. "An Exploration of Accountability Practices of School Counselors: A National Study." Journal of Professional Counseling: Practice, Theory \& Research 38, no. 1 (2010): 52-70.

Schmidt, John J. Counseling in Schools: Essential Services and Comprehensive Programs. Allyn \& Bacon, 2003.

Soapatty, Lisnawati. "Pengaruh Sistem Sekolah Sehari Penuh (Full Day School) Terhadap Prestasi Akademik Siswa Smp Jati Agung Sidoarjo.” E-Journal UNESA 2, no. 2 (2014): 719-33.

Suharto, Edi. "Menengok Kriteria Kemiskinan Di Indonesia: Menimbang Indikator Kemiskinan Berbasis Hak.” Jurnal Analisis Sosial, 2009, 31-39. 